Journal of Jazz Studies vol. 8, no. 2, pp. 174-177 (Winter 2012)

\title{
Response to Randall Sandke
}

\author{
Andrew Sanchirico
}

I would like to take the opportunity offered me by the Journal of Jazz Studies to respond to Randall Sandke's critique of my article, "Is Conventional Jazz History Distorted by Myths?" I will begin by acknowledging a shortcoming of my study that was identified by Sandke. Although I claimed the study included all jazz history books published since 1990, Sandke uncovered several jazz history books published since that date that were not included in the study. My failure to include these texts was inadvertent, but was nonetheless a serious error for which I offer no excuse. I was relieved that Sandke found no evidence to contradict my findings that the myths he identified are largely absent from the current jazz history literature. However, although my study was primarily concerned with jazz history books, the focus of Sandke's critique is on the teaching of jazz. Consequently, his critique shifts the focus of my article from books to teaching. Below are three examples of this.

1) Sandke states: "[Sanchirico] takes me to task for stating in my book, Where the Dark and the Light Folks Meet, that historical inaccuracies in the form of myths are still being taught on college campuses throughout the country." In fact, I did not take Sandke to task for stating that jazz myths are still being taught on college campuses. What I took him to task for was failing to provide sufficient evidence to support his claim that the myths generated by earlier jazz writers are still found in current jazz history books. As I stated in my article: "Sandke, however, makes very little effort to support his assertion that these myths are being perpetuated by present day writers and scholars. Sandke's failure to adequately support this assertion raises a question about its accuracy. This question was the impetus behind the present study."

2) Sandke states: "What Dr. Sanchirico presents in his article is one yardstick we may use to determine how jazz is taught today. But this approach is rather like sticking a yardstick in the middle of a lake (or sea) to measure its depth." This is a misrepresentation of my methods and objectives. I never claimed that my study was to be used as a measurement to determine how jazz

\footnotetext{
${ }^{1}$ Andrew Sanchirico, "Is Conventional Jazz History Distorted by Myths?" Journal of Jazz Studies 8/1 (Spring 2012): 57.
}

Copyright by author $(9) \$ \bigoplus \begin{aligned} & \text { Except where otherwise noted, this work is licensed under } \\ & \text { http://creativecommons.org/licenses/by-nc-nd/3.0 }\end{aligned}$ 
is taught today. My objective was to analyze the content of current jazz history books to determine the extent to which contemporary jazz historians are perpetuating the myths identified by Sandke. As I stated in my article: "The present study examined one aspect of Sandke's thesis: his assertion that recent jazz writers and scholars continue to perpetuate the exclusionary myths generated by earlier jazz writers."

3) Sandke states: "[Sanchirico's] fundamental argument is that the teaching of jazz, as revealed through jazz history textbooks used over the past twenty years, is nearly free of the mythology I object to in my book. But how can one know for sure? Once the classroom door is closed, a professor can have great latitude in how class is conducted." Nowhere in my article did I argue that my analysis of jazz history books revealed that the teaching of jazz is nearly free of the mythology objected to by Sandke. What I did conclude from my analysis is that the current jazz history literature is largely free from the mythology objected to by Sandke. As I stated in my article: "Thus, for the most part, the historians whose books were included in the study are not perpetuating the mythology of jazz . . . The present study suggests that the recent jazz historians have done an admirable job identifying the myths generated by earlier writers and replacing them with more factual information." 3

Sandke's critique is terribly misleading. Reading it gives the impression that my article was primarily concerned with how jazz is taught in colleges and universities. It also gives the impression that I erroneously and naively tried to equate the content of jazz history books with the content of jazz history courses. The opposite is true. The only place my article addresses the teaching of jazz is in the final paragraph where as the result of a JJS reviewer's criticism that my study is limited to textbooks and ignores academics, I included the following passage: "Sandke locates the perpetuation of jazz mythology in sources that extend far wider than the writers and books included in this study. In particular, he is especially critical of college professors who he accuses of using their courses to advocate an exclusionary viewpoint and to perpetuate jazz mythology. It could therefore be argued that the present study ignored precisely those sources that are most responsible for the perpetuation of jazz myths. I would contend, however, that the writers included in this study represent the mainstream of jazz scholarship and that their books reflect a

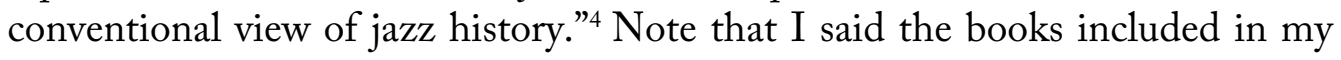

\footnotetext{
${ }^{2}$ Sanchirico, 77 .

${ }^{3}$ Sanchirico, 78.

${ }^{4}$ Sanchirico, 79.
} 
study reflect a conventional view of jazz history, not that they reveal how jazz history is being taught in college classrooms.

It could be claimed, of course, that I am the one doing the misrepresenting; that Sandke's book is about jazz pedagogy, not jazz historiography; that it is about academic ideologues, not mainstream historians. This is not the case, however. For although Sandke's book is highly critical of professors who use jazz to fight the negative effects of racism, he treats this as part of a larger problem, which is that conventional jazz history has been and continues to be shaped by ideologically-based theories that portray the music as an exclusionary art form. In this regard, he states, "Jazz as response to oppression' theories proliferated in the seventies, eighties and nineties and filtered into mainstream conventional wisdom. These beliefs were taken up by a new generation of jazz scholars eager to display their liberal credentials." ${ }^{5}$ That Sandke believes these myths are being perpetuated in the jazz history literature is evident from the following statement: "[W]hat follows will fill in many of the gaps of this storyline and refute much of the conventional wisdom found in standard jazz texts." And it is clear from the following overview of his book that Sandke believes the mythology of jazz as pervasive: "Then we'll return to the 1960s to see how radical and unpopular ideas evolved into mainstream conventional wisdom. I'll show how these ideas, along with attempts to achieve racial redress, have dominated the jazz world since the 1980s."

By shifting the focus of my article from books to teaching, Sandke draws attention away from the mainstream jazz historians-who were an integral part of his book - and places it on a subgroup of jazz historians: college professors who teach jazz history from an Afro-centric perspective. While Sandke acknowledges that jazz is most often taught as a music course, he explains that jazz courses can also fulfill requirements in diversity studies departments most typically black studies. He then states: "In this wing of academia, the black liberation struggle may well become the focal point of jazz history . . . . Out of this milieu has emerged an Afro-centric approach to jazz." How prevalent is this wing of academia? Sandke does not indicate, but he does claim that "there is a wealth of evidence, from course listings, student evaluations, professors' statements, and published papers and books, suggesting that the politics of racial grievance is an important element in the teaching of jazz for some

\footnotetext{
${ }^{5}$ Randall Sandke, Where the Dark and the Light Folks Meet (Lantham, MD: Scarecrow Press, Inc., 2010), 5.

${ }^{6}$ Sandke, 10.

${ }^{7}$ Sandke, 10-11.
} 
professors." It would be interesting to know how many jazz history professors fall into this category, what percentage of jazz courses they teach, and what percentage of students take these courses. My guess is that the figures would be quite small.

Sandke concludes his critique by criticizing my article for failing to recognize that his treatment of race relations in the jazz world differs from and expands upon that which appears in the existing literature. In response to Sandke, I want to stress that my study was more concerned with the content of the current literature than with the content of his book. Although my findings revealed that Sandke exaggerated the extent to which jazz myths are found in the current texts, I do not wish to imply that his book offers no new insights or contains no new information about the interracial aspects of jazz. On the contrary; I believe Where the Dark and the Light Folks Meet contains much valuable information. For example, while I do not think that his chapter on the white jazz audience shatters any myths, it does contain a wealth of information about black artists performing jazz for white audiences throughout the music's history and identifies many of the venues in which this racial interaction occurred. I will no doubt return to this chapter in the future as a reference source. Thus, despite my disagreements with Sandke's book, I believe it is a valuable addition to the jazz history literature.

\section{ABOUT THE CONTRIBUTOR}

ANDREW SANCHIRICO holds a $\mathrm{PhD}$ in Sociology from the University at Albany, State University of New York. He was a Senior Research Scientist at the University at Albany until 2011 and is now an independent scholar focusing on the social history of jazz. He is currently working on papers that examine the use of jazz as metaphor and the cultural transformation of jazz. 